\title{
地方都市における痴呆性高齢者 CASE STUDY OF DAILY LIFE IN の住まいと住み方に関する調查 HOUSES OF THE ELDERLY WITH 報告 DEMENTIA
}

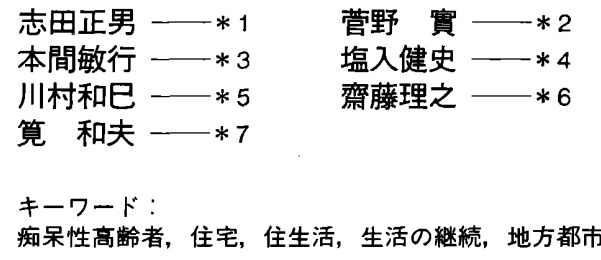

Keywords :

Elderly with dementia, House, Daily life, Keep it normal, Local town

$\begin{array}{ll}\text { Masao SHIDA }-* 1 & \text { Minoru KANNO - }-2 \\ \text { Toshiyuki HONMA } * 3 & \text { Takeshi SHIOIRI - *4 } \\ \text { Kazumi KAWAMURA - } * 5 & \text { Masayuki SAITO - *6 } \\ \text { Kazuo KAKEHI }-* 7 & \end{array}$

The purpose of this report is to find the needs of people with dementia who live in their own houses. We have researched the daily life of 31 cases in Miyagi prefecture. There are many barriers and dangerous places in their houses. And some of them were injured seriously. Most of them live in Tsuzukima-rooms which are one of the old type of Japanese houses, enjoying the time with the neighborhood in this local town. They keep their normal living situation the same. We explain some conditions that enable them to continue to live with their families in their houses.

\section{1.はじめに}

我が国では1998年現在、高齢化率が $15 \%$ を超え、今後さらに増 加が予測されており、在宅福祉を基調にした地域福祉の推進が急務 の課題となっている。そのためには、在宅福祉の基盤となる住宅の 整備向上が久かすことができない。特に痴呆性高齢者の在宅生活は、 これまで高齢者本人とそれを支える家族の並大抵でない我慢と労苦 でかろうじて維持されてきた。しかし痴呆性高齢者数の増加とそれ を支える世帯人員が减少した今日の社会にあっては、この生活環境 の整備向上には、医療・保健・福祉・建築等の関係者が一段と連携 を強めて取り組むことが求められている。

本研究は、第一には現在の在宅生活の住み方調查を通してこれら 家族のための住宅計画への知見を、そして第二には、その中に見ら れる「家庭的なもの」の存在と、その成立基盤を明らかにすること を通して、痴呆性高龄者の居住施設の設計計画に資する知見を得る ことを目的としたものである。

\section{2. 課题と方法}

この研究では、1)現在の地域社会の中で、また現在住んでいる住 宅での痴呆性高齢者の生活の場の特性、2)痴呆性高龄者の住宅内で の問題行為、3) 同じく住宅内での高齢者の残存能力を生かした行為 に着目し、それらと主体条件や空間条件との関係を分析した。その 中で本編は、(1)痴呆性高齢者を介護している家庭の世帯と住宅の特 性、(2)住宅内外の物的障害とそこでの行動やケガの発生状況、(3)住 み方の内で、日中のくつろぎ・就寝・排泄・入浴などの最も基本的 な行為の展開。(4)それに加え残存能力を活かして、自らがす寸んで 他と交流し、自由な時閒を楽しみ、自分らしい生活を継続する態様、
いわば「この人の、この住まいでの生活らしさ（これを住生活のア1 デ疒仢イとした）」を明らかにする。そしてそこから、新たな施設の 計画にも継承されるべき「家庭的なもの」を抽出しようとした。

このために夷施した調查は、本調查に先行して行なった「宮城県 にお汁る高齢者の住宅事情に関する研究」注1) の結果を参考に、宮 城県内を高齢者の世帯と住宅特性に基づいて下記の 3 地域に区分し、 各地域で痴呆性高齢者の住宅を対象に、介護者からのヒヤリングと 生活の場の観察を行った。調查期間は96年12月から97年 8月まで。 対象は原則として持家とし、1)保健婦記録等の既存資料調查と 2) 自 宅訪問調查の 2 段階で行った。対象地と調查戸数は、a. 大都市地域 として仙台市から15戸、b. 都市化地域として気仙沼市から 8戸、c. 農山村地域として田尻町から 8戸とした。いずれも各市町の保健也 ターの紹介を受けた後、調查者が直接各住戸を訪問した。

\section{3. 対象者の世帯および住宅の特性}

対象者の一覧を表- 1 に示した。年齢では、80歳以上の高齢者が 31 例中 17 例で、特に気仙沼、田尻に多く、仙台の対象者は比較 的若い人が多い。次に痴呆症の進行程度を日常生活動作能力 (流-2. N-ADLLよ)でみると、重度の者が 4 例あり、残りは中等度 7 例、軽度 10例、境界が10例である。重度の者を除いてほとんどの者が、各市 町のデ体ービ犺多に通っている。また、高齢者と同居している家族 は、ひとり暮らしはく田尻-8〉の 1 例で、介護者と 2 人だけの世帯が 7例ある。このうちく仙台-6〉と〈仙台-8>の 2 例はへ川パーを雇っている。 あとは 3 人以上の世帯である。世帯人数は、一方に孫世代が都市部 ほか他地域に転出し少人数となったものがあり、他方 3 世代同居で

\footnotetext{
1 東北工業大学工学部建築学科 教授. 博士 (工学)

(干982-8577 仙台市太白区八木山香澄町 35-1)

*2 東北大学大学院工学研究科教授. 工博

*3 宮城工業高等専門学校建築学科 教授. 工博

*4 東北大学大学院

*5 NTTファシリテーズ

*6 東北大学大学院

*7 東北学院大学工学部 教授・工博
} 
多人数世帯というように多様である。主に介護にあたっている人は 配偶者か娘である場合が多く、息子の妻 (嫁) も高齢の者は介護する が、若い者はしていない例が多い。結果的に、対象は独り暮らしの 1 例を除いて、夜閒はもちろん日中も誰かが、常時高龄者の介護を している。

住宅では、気仙沼と田尻は昭和 30 ～40年代に建てたものが大半で、 新しいものは 1 例だけである。これに対して仙台は新しい住宅が多 く、平成以降に建てられたものが半数ある。住宅の各部に手すりを 付けたり、広さや段差などに気を配って建てられたものは、この建 設時期に対応していて、これが見られるのはほぼ平成以降のものに 限られている。また発病後に増改築をした例も少なく、あってもト レの手すり程度である。これに加えて、農村部の田尻には浴室や便所 が屋外のものもある。建て方はく仙台 -9 〉共同建持家の 1 例を除い て全て一戸建持家で、階数は 2 階建てのものが多い。この 2 階建て の場合も対象高龄者の生活の場は、〈気仙-3〉の 1 例を除いて全部 1 階を使用している。仙台の対象の中には生活の場を子世帯と $1 、 2$ 階で完全に分離したいわゆる二世帯住宅が 2 例ある。その建設時期 は2 例とも平成8年で新しい。居室数は 6〜7室前後が支配的であり、 気仙沼、田尻のものが仙台よりも平均して 1 室ほど大きい。敷地面 積は気仙沼、田尻の半数が 100坪以上である。これに対して仙台は 100 坪以上のものは $1 / 3$ 程度で、農村部に比心゙小さいものが多い。

以上のように住宅特性は、大都市仙台の新しいものと、地方都市 ・農村の気仙沼・田尻の閒で相違が見られる。

\section{4. 日中いつも居る培}

対象の疾呆性高齢者が日中いつも居る場の室特性、しつらえ、そ こからの景色を表-2に示した。その場は、生活動作能力が重度で ある者以外は、多くはその住宅の居間と呼ばれる部屋の、定まった 位置に坐っている。住-3）本編では、その部屋をユカ坐が主体で生活 しているものを茶の間、イス坐のものを北゙放と呼ぶ。

この場は、仙台の特に建設時期が新しいものに北゙ンがが多く、気 仙沼と田尻のものは、ほとんどが茶の間である。このように高龄者 が居住する住宅の場合も、都市化の程度と対応して居室の洋室化の 地城差があることがわかる。居る場所がこの茶の閒や师゙ング以外の 例は、重度で寝室のベッド上で過ごす 3 例と、店舗付き住宅で日中 は茶の間に人がいないため寝室にいる例〈気仙一3、瞵に㠩林があ りながら和室の寝室にいる例〈仙台-7〉、子世帯棟の茶の間・齊゙ン多 には出ていかずに個室で過ごす例〈仙台-11〉などである。全般的に、 师ングという形式は新築住宅に多いこともあって、ここで過ごすと いうものでも「落ち着かないので寝室に戻る」という例（次ページ 写真-1）などが散見される。特に冬期はこたつが好まれることもあ って、北ングでのイス・ソファーの生活が定着している例が少ない。

こたつの使用は、どの家もあまり広くない居室の中央部に大振り のこたつ掛けを広げ、それでなくても足取りが不安定な高龄者の歩 行の邪魔になったり、活動を不活発にさせていて合理的でない点が 多い。しかし、現在ではこれに代わる暖房機器も普及しておらず、 寒冷地の冬期のユカ坐の生活の中心を占めている。

テレビも同様に、ほとんどの住宅で日中の居場所に置かれている が、放映内容にはあまり関心がない高齢者が多いこともあって、そ の正面には介護者席があり、高齢者席はその脇のことが多い。
表一 1 ，疾染性高龄者住宅調查・対象者一覧

\begin{tabular}{|c|c|c|c|c|c|c|c|c|}
\hline & \multicolumn{3}{|c|}{ 対 象 者 } & \multicolumn{2}{|c|}{ 同居 家族 } & \multicolumn{3}{|c|}{ 敫地-住宅規模 } \\
\hline & 性別 & 年离 & 作能力 & 家族型 & 人数 & 建設年 & & 居室数 \\
\hline 仙台 I & 勇 & 69 & 界 & $\mathrm{Cc}_{\mathrm{c}}$ & 4 & S. 44 & $330 \mathrm{~m}^{2}$ & 4 室 \\
\hline 仙台 2 & 男 & 65 & 侱度 & $\mathrm{C}$ & 2 & S. 61 & 230 & 5 \\
\hline 仙台 3 & 女 & 67 & 中等度 & $\mathrm{Ccg}$ & 7 & 䣹前 & 528 & 13 \\
\hline 仙台 4 & 男 & 57 & 軽 度 & Ccg & 7 & II. 8 & 363 & 9 \\
\hline 仙台 5 & 男 & 92 & 雪 度 & PLcg & 5 & H. 8 & 330 & $\begin{array}{l}7 \\
\end{array}$ \\
\hline 仙台 6 & 女 & 63 & 重度 & $\bar{C}$ & $\overline{2}$ & II. 2 & 231 & 5 \\
\hline 仙台 7 & 女 & 81 & 度 & $\mathrm{Ccg}$ & 6 & S. 52 & 347 & 8 \\
\hline 仙台 8 & 男 & 61 & 境 界 & $\bar{c}$ & 2 & II. 3 & 264 & 4 \\
\hline 仙台 9 & 男 & 65 & 媑 度 & $\overline{\mathrm{C}}$ & 2 & S. 53 & - & 4 \\
\hline 仙台 I0 & 男 & 67 & 境 界 & $\overline{\mathrm{Cc}}$ & 3 & 5.36 & 132 & 6 \\
\hline 仙台 11 & 勇 & 85 & 量 度 & PLCCB & 6 & H. 7 & 264 & 8 \\
\hline 仙台 12 & 勇 & 66 & 境 界 & Cc & 3 & S. 47 & 215 & 5 \\
\hline 仙台 I3 & 䙲 & 71 & 中等度 & $\mathrm{Cc}$ & 3 & S. 26 & 165 & 6 \\
\hline 仙台 14 & 女 & 91 & 重 度 & $\mathrm{PLC}_{\mathrm{g}}$ & 4 & II. 3 & 281 & 7 \\
\hline 仙台 15 & 女 & 82 & 重 度 & PLC & 3 & II. 5 & 231 & 6 \\
\hline 気仙 1 & 女 & 84 & 境 界 & PLc & 3 & S. 42 & 83 & 6 \\
\hline 気仙 2 & 女 & 86 & 中等度 & PLC & 2 & S. 40 & 264 & 7 \\
\hline 気仙 3 & 女 & 83 & 中等度 & PLCg & 4 & S. 36 & 231 & 9 \\
\hline 気仙 4 & 女 & 73 & 度 & $\overline{\mathrm{C} \mathrm{cb}}$ & 5 & S. 46 & 990 & 11 \\
\hline 気仙 5 & 男 & 84 & 中等度 & $\mathrm{C}_{\mathrm{c}}$ & 4 & S. 45 & 330 & 13 \\
\hline 気仙 6 & 女 & 87 & 中等度 & PLc & 3 & S. 15 & 175 & 7 \\
\hline 気仙 7 & 女 & 70 & 中等度 & PLCCg & 6 & 䇅前 & 990 & 7 \\
\hline 気仙 8 & 女 & 86 & 境 界 & PLc & 2 & S. 48 & 380 & 7 \\
\hline 田肩 I & 女 & 78 & 重 度 & $\overline{P L c}$ & $\overline{2}$ & S. 56 & 330 & 4 \\
\hline 田尻 2 & 女 & 93 & 怪 度 & PLc & 3 & 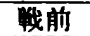 & 1320 & 8 \\
\hline 田肩 3 & 女 & $\overline{86}$ & 蕡 & $\mathrm{C}_{\mathrm{c}}$ & 3 & S. 25 & 148 & 3 \\
\hline 田尻 4 & 男 & 82 & 境 界 & Plec & 4 & H. 5 & 297 & 5 \\
\hline 田尻 5 & 女 & 74 & 怪 度 & PLeg & 4 & S.31 & 264 & 7 \\
\hline 田尻 6 & 女 & 83 & 度 & PLCg & 4 & S. 55 & 990 & 9 \\
\hline 田尻 7 & 女 & 91 & 境 界 & PLcg & 4 & S. 26 & 380 & 9 \\
\hline 田尻 8 & x & 80 & 境 界 & $\mathrm{PL}$ & 1 & S. 42 & 124 & 3 \\
\hline
\end{tabular}

*日常生活的作能力はN-ADI，重症度評価による

**家族型仕、PI，配偶者店し c 本人夫嬠 $\mathrm{c}$ 子世代 $\mathrm{g}$ 孫世代

\section{表‥ 2. 日中いつも居る場}

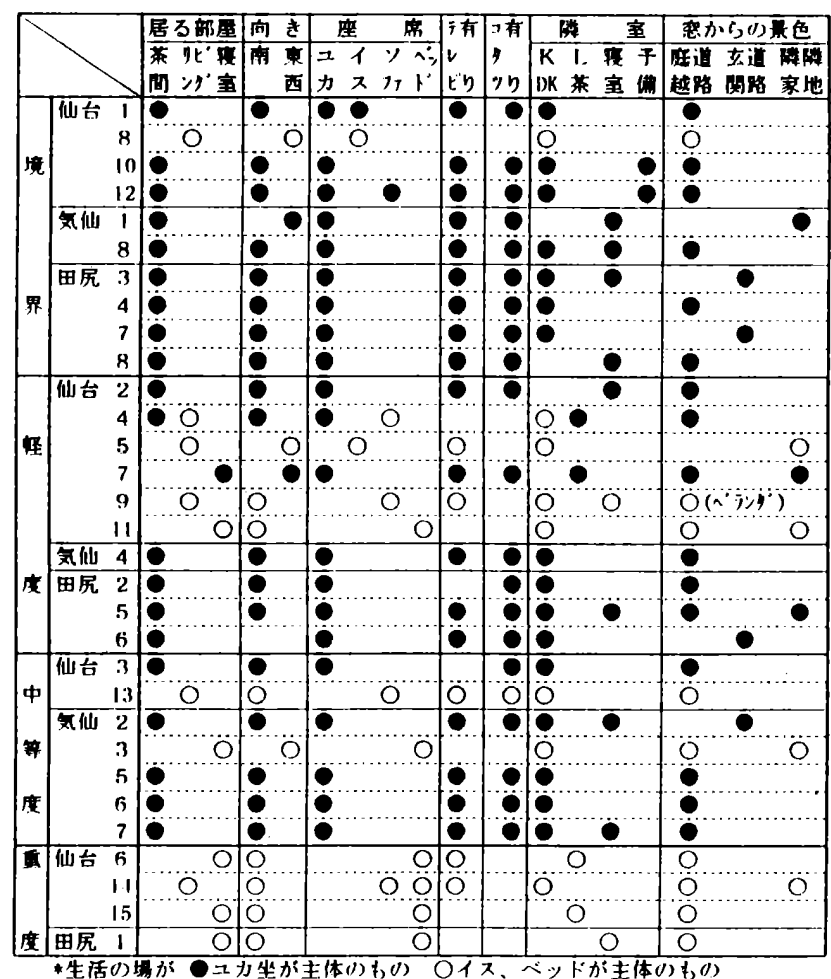


また、日中いる場は食事の場とのつながりも強い。動作能力が重 度や中等度でバッドに運んで食べるもの以外は、食事の場は、いつ も居る茶の間または㠩゙ングか、隣接のD Kでとっている。特に冬期 にこたつを使用する住宅では、茶の閒でこたつに入って食べるもの が圧倒的に多い。

外部とのつながりでは、敷地にまだわずかな余裕のある対象住宅 では、前面にミセ部分をもつ店舗付き住宅の場合を除いて、居室の 方位は南側の庭に面してとられるものが支配的である。その場合、 居室の北側に隣接する炊事・食事空閒との行き来が多いので、介護 者の席がそちら側にとられることが多い。そのため、高齢者席は必 ずしも南の開口部向きではない。しかし、立ち上がれば庭越しに道 路が見え、人の動きを眺められる場にある。また写真-2の例のよう に、〈気仙 $-2,-5,-7>$ や田尻 $-2,-3,-5,-7>$ などは、この家を訪れる 者の顔が見え、話がしやすい位置に高龄者の座を置いている。

なお、重度で日中いる場がベッドの上である 3 例 (写真-3 他) の 場合も、体調や気候を見ながら、茶の間や师゙ングに車椅子で運ばれ、 庭と介護者が見える場所で時を過ごすことも少なくない。

\section{5. 生活の埥の物的障害とケガ}

5-1. 住宅内外のレベル差など

現在の住宅では内外に物理的な障害をもつものが少なくない。 仙台や気仙沼の住宅では一歩外に出ると車の通行が多いことに加え、 特に郊外部に開発された住宅地に建つものには、車道と玄関までの 間に 4 〜 段の段差をもつものが多く、しかも玄関ポーチ等の段差 には手すりがない。〈仙台-15〉などは、歩行不可となった高齢者を背 負って介護者は10数段の階段を上下している。また〈気仙-1〉は、本

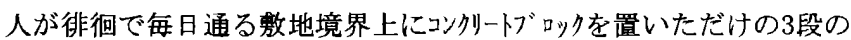
階段がある。室内では、新築のものには階段、卜化、浴室に手すりを 付けたものが散見されが、大半の住宅では、居住者自身はあまり気 にかけていないことが多いが、不安定な場が多く見られる。く気仙2〉は家の中で家具を伝い歩きしているが、その家具は固定されてお らずグラダラ動く。加えて、開放的な間取りで手すりは付けにくい。 また段差も多い。〈気仙-4〉や〈田尻-3〉は母屋部分と屋外にあるトイ レとの閒に、またく気仙-7〉やく田尻-2〉はかつて土閒や板の閒だった 部分と畳が敷かれた居室との閒に、いずれもレベル差や高い敷居が ある。そのような場で、表ー3に示したような歩行能力の痴呆症の 高齢者が生活している。

\section{5-2. 住宅内外でのヶガ}

対象高齢者は、日常生活の行動能力が低下している上に、危険を 回避する判断力も衰えているものが少なくない。加えて俳䧃を繰り 返す者もいる。したがって表-4に示したように、骨折などの大き なケガをしたものも非常に多い。この中で、仙台は他の 2 市町に比 べそれがやや少ない。それは対象者に比較的若い人が多いことにも よろうが、これに加え表ー3に示したように、周囲が車などの危険 性が高いために、本人や介護者が外出を控える、または止める傾向 が見える。これらのケガは屋外に限らず室内でもあってく仙台-13〉 は歩行中に足がもつれて転倒し、〈気仙-8〉は就寝中にベッドから落 ち、〈田尻-1〉も不在の介護者を捜そうとベッドから落ちて骨折をし ている。またく田尻-3〉は寝たきりの夫の異常にあわてて、痴朵の妻 が日頃慣れている茶の間と寝室の段差でつまずき、腕と腰を骨折し

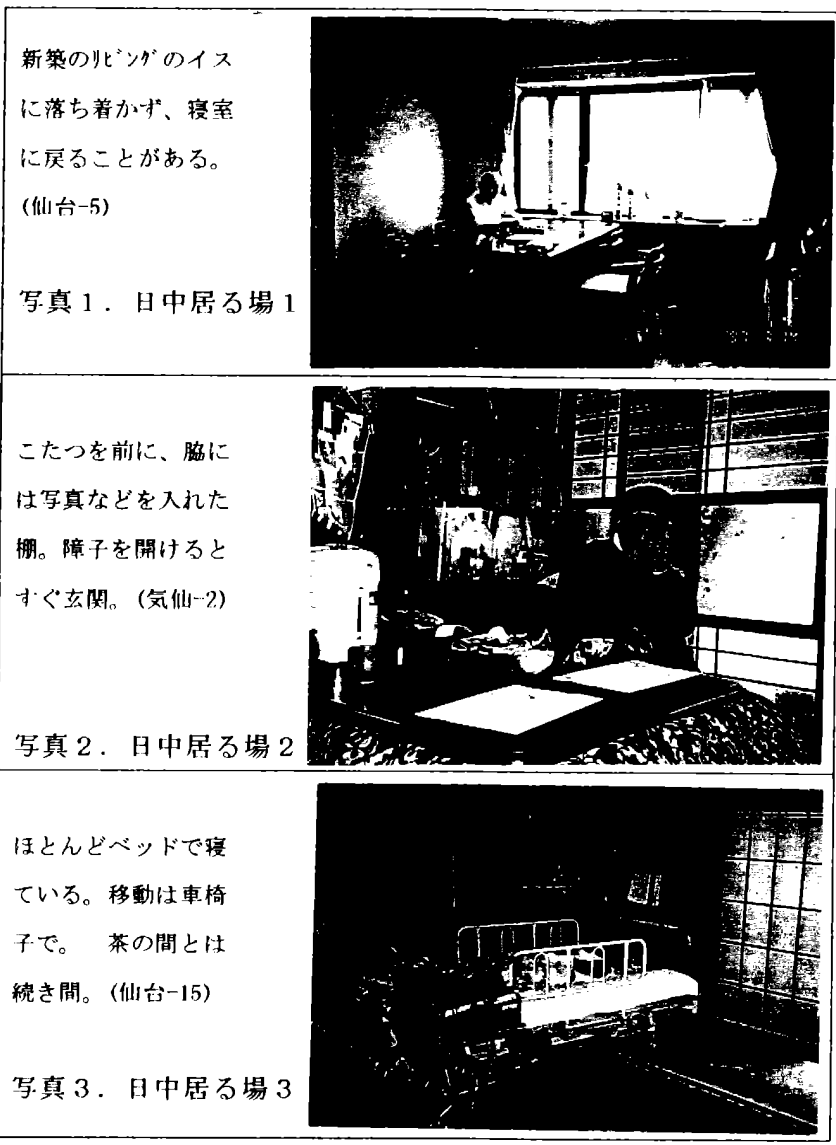

表-- 3. 住宅内外での步行

\begin{tabular}{|c|c|c|c|c|c|c|}
\hline & \multicolumn{5}{|c|}{ 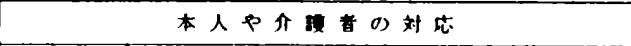 } \\
\hline & & $\begin{array}{l}\text { n. 独りで出 } \\
\text { て频く }\end{array}$ & h. 焟り心配 & c. 斻が心眍 & d. 亩内だけ & e. 盍内6介 \\
\hline (塿 罪) & 仙台4人 & (10) & (8) (12) & (1) & & \\
\hline 㛒時间の & 気(112人 & (1) (8) & & & & \\
\hline 独步可能 & 田尻1人 & (4) (7) (8) & (3) & & & \\
\hline (怪 库) & 仙台6人 & & (2) & (4) (9) & (5) (7) (11) & \\
\hline 㚢步行 & 気仙1人 & & & (4) & & \\
\hline 陵段困籍 & 田层3人 & & (6) & (2) (5) & & \\
\hline (中等度) & 仙台 2 人 & & & & (3) (13) & \\
\hline 㐾い步き & 気仙5人 & & & (5) (7) & (2) (3)(6) & \\
\hline 階股不能 & 田尻0人 & & & & & \\
\hline$\left(\begin{array}{ll}1 & 0\end{array}\right)$ & 仙台了人 & & & & & (6) (11) (15) \\
\hline 隹たきり & 保仙o人 & & & & & \\
\hline 坐位可能 & 田尻1人 & & & & & (1) \\
\hline
\end{tabular}

表一 - . 痴呆が進行して以降けケガ

\begin{tabular}{|c|c|c|}
\hline 仙台 10 & 男 & 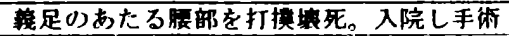 \\
\hline 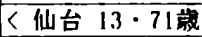 & 勇） & 室内で元倒し頭を打ち 3 鳎程 \\
\hline 仙台 $14 \cdot 91$ 葴 & 女〉 & ベッドから何し肯折。床スレで入院 \\
\hline 1·84歳 & 女 > & 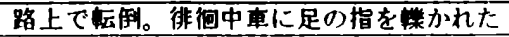 \\
\hline 気仙 $3 \cdot 83$ 阆 & 女> & 外出中、平坦な路上で云倒、頭郭を打撗 \\
\hline (気仙 $5 \cdot 81$ 筬 & 男） & 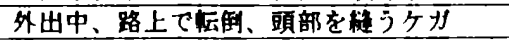 \\
\hline <気仙 $6 \cdot 87$ 鬲 & 女 & 路上でつまずき伝佂、骨折で 40日間入院 \\
\hline <気仙 $7 \cdot 70$ 縅 & 女 & 路上で臸倒、類にケガ、何針か棁った \\
\hline 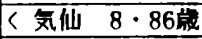 & 女 > & シッドから枟洛して骨折 \\
\hline 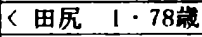 & 女> & 不在け意子を按そうとベッドから标落骨折 \\
\hline <田尻 $2 \cdot 93$ 鬲 & 女> & 路上で后倒、骨折 \\
\hline$<$ 田尻 $3 \cdot 86$ 馓 & 女? & 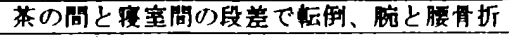 \\
\hline 田㞔 $5 \cdot 71$ 噦 & & 8 \\
\hline
\end{tabular}


ている。介護家族の中には夜間の徘徊に備え、鍵をかける、飼い犬 がしらせる、店頭に置かれているような光センサーを設置、などで 対応しているものもある。しかし屋外の危険性を彩念しつつも、俳 徊などを止めたときの不機嫌さを避けて、結果的には大きなケガが あるまで忙手を打たなかったというものも多い。痴呆性高齢者の行 動の自由の尊重と安全性をどうバランスさせるか、在宅介護の難し さがある。また前記のように対象住宅も安全上の問題筒所は内外と も多い。しかし介護者を含む家族は、住宅内についても必ずしも早 急に改造しようとしていない。それには経費の問題があろうが、高 齢者が身体で覚えている所を今更変えない方がいいという考え方も ある。これは、新たな事や状況への適応力に乏しい対象者にとって、 大切な点であると考える。しかし、小規模の改造で危険箇所を除去 する余地もまだまだある。この改造問題は、記憶された空間をいか に継承しつつ実施するのか、また、そのタイミングはどうあるべき か、ぼんやりとは必要性を感じつつ先延ばしにしている家族に、奏 施を決断させるには、どんな主体のどんな手段が有効か等 崔-4)、今 後より一層、検討を重ねる必要がある。

\section{6. 就里および排泄、入浴の场 6-1. 就安の埥}

高齢者の寝室は、表 -5 に示したように(1)日中居る場の隣にとる、 (2)そこと離して介護者の寝室の隣にとる、の 2 多价が多い。発病以 前は寝室は 2 階にあったというものも、大半は 1 階の(1)か(2)のいず れかに移している。これは、発病以前に造られた住宅の間取りの規 定を受けつつ、住み方としては昼の介護か、夜の介護かのいずれか を重視した結果といえる。この両夕隹と現在の生活動作能力との間 に明確な対応は見られない。この他には、不便だが昔からの寝室を 変えないという例く仙台-3〉や、ト化に近い所を選んだ例く気仙-7、田 尻ー 6 〉、日当たりを重視した例〈気仙一5 などがある。

\section{6-2. 排泄と入浴}

気仙沼、田尻の両市町は、現在全市の下水道化が進行中で、それ を期にトイレの水洗化・洋式化が行われている。〈気仙-7〉は外卜化 · 浴室を室内化し、同時に手すりもつけた。しかしまだ和式のものや、 農村地域の古い住宅では外便所も残されている。気仙沼や田尻で、 日中はトイレに行くが、夜間は部屋に置いたボータブル化を使用する 者が多いことに見られるように、これらの事例は室内にポータブ忆 が持込まれるのも早い。これに対して仙台は水洗化が早かったので、 対象の住宅は水洗・洋式化をめぐる混乱は少ない。またポータブ忆化 を持ち込むものも少ない。しかし狭さと位置に問題があって、必ず しも満足を得られていない。特に新築住宅では夜閒の電気のス伊を 始め、ト化の位置さえ不明で混乱するものも見える。

入浴注、生活動作能力が境界や軽度の事例は、ほとんどが自宅の 浴室で入っている。しかしこの場合も洗髪を介護してもらう者は多 い。また軽度の者には介護者と一艃に入るか、ひとりの場合も介護 者はかなり気を配って付き添っている。生活動作能力を問わず、入

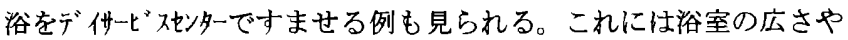
設備、介護者の体力などが関わっている。浴槽が床置き型で、足を 高く上げ跨がなければならないのに手すりの設置がないものも少な くない。〈田尻-8〉などは自宅の風呂は怖いので、デ仿ービスでしか入 らないという。また中等度ではへルパーが入浴に手を貸しており、
表一 5 。就誛の場と葠方

\begin{tabular}{|c|c|c|c|c|c|c|c|c|}
\hline & \multicolumn{4}{|c|}{ 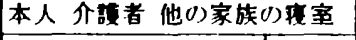 } & \multirow{3}{*}{ 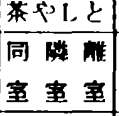 } & \multirow{3}{*}{ 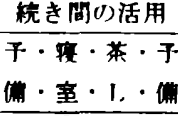 } \\
\hline & & & 本人の & 哽 & $\vdots 1$ 䧼 & 2 階 & & \\
\hline & & & 安 至 & 宰 & 别 室 & 別 坠 & & \\
\hline & 仙台 & & 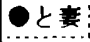 & & & 息夫姆 & $\Delta$ & 予霜 \\
\hline & & 8 & ○と表 & & & & $\mathbf{A}$ & \\
\hline & & 10 & 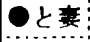 & & & 息 & $\Delta$ & 茶と予 \\
\hline & & 12 & ○と㤗 & & & 娘 & $\Delta$ & 莱と子 \\
\hline & 気仙 & 1 & $O$ & & & 息夫㛿 & $\Delta$ & (7) 2 萧 \\
\hline & & 8 & 0 & 嫁 & & & $\Delta$ & F冲 \\
\hline & 田尻 & 3 & Oと夫 & & 息 & & $\Delta$ & (1) と茶 \\
\hline 界 & & 4 & e & 娘 & & 息 & A & 垵 \\
\hline & & 7 & 0 & & 息夫嫡 & 孫 & 4 & 于と蕅と予 \\
\hline & & 8 & $\mathrm{O}$ & & & & $\Delta$ & 实上莱 \\
\hline & 仙台 & 2 & 도․ & & & & $\Delta$ & (1)<䒺 \\
\hline & & 4 & 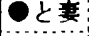 & & 息 & 息夫㛿 & $\Delta$ & 1.と子 \\
\hline \multirow[t]{5}{*}{ 蛙 } & & 5 & … & 傢 & & 腺夫癟 & $\Delta$ & (1) \\
\hline & & 7 & ○と夫 & & & 息夫㛿 & $\Delta$ & 于 $\subset$ (T) \\
\hline & & 9 & 6 & 㛃 & & & $\Delta$ & 定と口 \\
\hline & & 11 & 2 & & & 娘 係 & $\Delta$ & 萧字 \\
\hline & 気仙 & & ○と夫 & & & 息夫㛿 & $\Delta$ & 予と事 \\
\hline \multirow[t]{3}{*}{ 度 } & 由展 & 2 & $O$ & 息夫㛿 & & & $\Delta$ & 叟と震 \\
\hline & & 5 & O & 息夫㛿 & & & $\Delta$ & 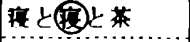 \\
\hline & & 6 & Oと嫁 & 息 & & 孫 & $\Delta$ & テと千 \\
\hline & 仙台 & & ○と夫 & & & 息夫妩 & $\therefore$ & 千と民菜と予 \\
\hline \multirow[t]{2}{*}{ 中 } & & 13 & Oと妾 & & & 总 & $\Delta$ & \\
\hline & 気仙 & 2 & Oと嫁 & & & & $\Delta$ & (S) \\
\hline \multirow[t]{2}{*}{ 第 } & & 3 & Or家 & & & 息 愻 & A & 予遇 \\
\hline & & 5 & orc & 息夫㛿 & (全部) & (2階) & 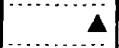 & 度と(1) \\
\hline \multirow[t]{2}{*}{ 度 } & & 6 & $O$ & \begin{tabular}{l} 
息 \\
\hdashline
\end{tabular} & & 家 & $\therefore$ & 度之象 \\
\hline & & 7 & O夫孫 & & 母 孫] & & $\Delta$ & 子と垵 \\
\hline \multirow[t]{3}{*}{ 重 } & 仙台 & 6 & OrII & & & 夫 & 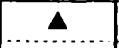 & (1) \\
\hline & & 14 & OとII & & & 息夫㛿 & $\Delta$ & \\
\hline & & 15 & 0 & 娘 & & 娘 ()$夫$ & $\Delta$ & 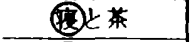 \\
\hline 度 & 田层 & 1 & $\mathrm{O}$ & 息 & & & $\Delta$ & 瘦 と露 \\
\hline
\end{tabular}

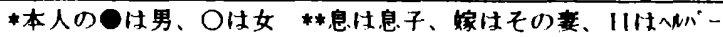

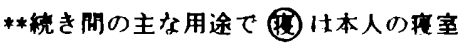

表 -6 . 排泄と入谷の場

\begin{tabular}{|c|c|c|c|c|c|c|c|c|c|}
\hline & \multicolumn{3}{|c|}{ 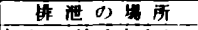 } & 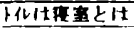 & \multicolumn{3}{|c|}{ 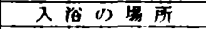 } & \multirow{2}{*}{ 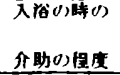 } \\
\hline & & $\sqrt{11 k}$ & $\begin{array}{l}-71 \\
x<12\end{array}$ & 47 & 同事事 & 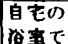 & $\frac{71}{t-t x}$ & 入 & \\
\hline & futs & $\overline{9}$ & & & $\overline{0}$ & 0 & & & 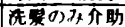 \\
\hline & & 6 & & & 0 & 0 & & & \\
\hline 境 & 10 & 6 & & & Ö & 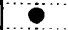 & & & axz \\
\hline & 12 & 0 & & & Ö & 6 & & & 見てい弓 \\
\hline & 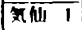 & 9 & & & $\mathrm{O}$ & Q. & $\overline{0}$ & & \\
\hline & 8 & 0 & 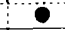 & $\because$ & 0 & 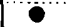 & & & \\
\hline & 田皃 & $\overline{0}$ & & & (2) & $\overline{\mathbf{D}}$ & & & \\
\hline 界 & 4 & 0 & & & 0 & $\ddot{\theta}$ & & & \\
\hline & 7 & $\because$ & 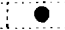 & $\bullet$ & 0 & 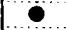 & & & 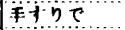 \\
\hline & 8 & 0 & & & 0 & & 0 & & 自宅付怰心 \\
\hline & fill 2 & $\overline{\mathbf{\theta}}$ & & & $\bar{O}$ & $\overline{\mathbf{D}}$ & & & 洗( 水介助 \\
\hline & 4 & 6 & & & 0 & 0 & & & 完てい \\
\hline n. & 5 & $\ddot{\theta}$ & & & O & & 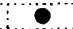 & & $=1(0){ }_{A}$ \\
\hline & 7 & 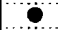 & & e & $\dddot{O}$ & $\ddot{0}$ & 0 & & 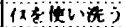 \\
\hline & 9 & i & & 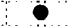 & Ö & 0 & & & 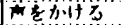 \\
\hline & 11 & 0 & & 0 & 0 & 0 & 0 & & 腺が大害苦 \\
\hline & 氛仙 4 & $\overline{0}$ & & & (Q) & 웅 & & & 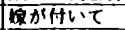 \\
\hline 度 & 西㞣 2 & e & $\overline{0}$ & & 0 & $\overline{8}$ & & & 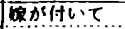 \\
\hline & 5 & 0 & & & 0 & 6 & 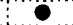 & & \\
\hline & 6 & 6 & 0 & $\theta$ & Ö & 0 & & & \\
\hline & 好台 : & & & $\bar{Q}$ & (2) & Q & & & 㐫方付いて \\
\hline$\phi$ & 13 & & & 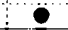 & 0 & & 0 & & $=1(0) \lambda_{x}$ \\
\hline & 氮化 2 & & $\overline{0}$ & $\overline{0}$ & $\bar{\rho}$ & $\dot{A}$ & & & $n \because$-が拳层 \\
\hline \# & 3 & a & 0 & 0 & 0 & $\ldots$ & 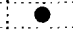 & & $=1$ (o) \\
\hline & 5 & $\ddot{\theta}$ & 0 & $\bullet$ & 0 & $\ddot{\theta}$ & & & $1 \neq+y$ on \\
\hline 庵 & 6 & $\Delta$ & 6 & Oे & 0 & & 6 & & $\mid=1$ ioj \\
\hline & 7 & $\ddot{\Delta}$ & & $\ddot{\theta}$ & 0 & 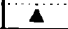 & & & 手1少部 \\
\hline 面 & fill & & & - & $\bar{O}$ & & & $\star$ & 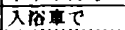 \\
\hline & & 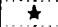 & 0 & 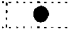 & 0 & & & $\star$ & Antor \\
\hline & 15 & $\star$ & & $\theta$ & 0 & A & & $\star$ & 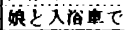 \\
\hline 度 & 而㧁 । & A & 6 & - & 0 & $\bar{A}$ & & & 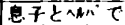 \\
\hline
\end{tabular}


重度の3 例は入浴車を使って入浴させている。

以上の上うに、対象住宅は浴室の狭さ、浴槽の高さ、手寸りの末 設置、介護者の体力との関係などに、問題を残しているものが多い。

\section{7. 続き间の活用}

対象地域の住宅は、特に気仙沼と田尻のものには続き間座敷や、 茶の間と他の和室を䐿でつなぐ閒取りのものが多い。これに対して 仙台の新築住宅にはそれが少ない。いわゆる続き間座敷については、 床の間や書院を付けた多人数接客を意識した部屋を、条件の良い位 㯰に日常空けておくことが不合理であると指摘され尽くした。しか し、対象世帯のように介護を必要とする者がいる家庭で注、表-50 右欄及び図ー2．図一 3 に示したように、これがよく活用されてい る。隣のベッドの高齢者を見ながら、時には間仕切を閉じて介護者 が茶の閒で生活する例、逆に茶の閒の気配を感じつつ自室にこもる 高齢者、夜間隣室の高龄者の声が聞こえるところで寝る例、などで ある。これら任伝的な和風住宅がもっていた連続性、開放性を生 かした住み方とも見られ、高齢者の住まいの居室閒の関係を考える 上で示晙に富む。

なお、高㱓者の寝室を隣室と続き閒にしない場合は、(1)広い和室 または洋室をとって介護者が同室寝する〈仙台-4〉〈仙台-8〉、(2)狭い 葠室でべッド脇にふとんを並へてへル゚ーなどが添い寝〈仙台一6〉気仙 -7〉〈田尻-6〉などがある。またく仙台-13〉は高龄者が問題行為が多く 目が離せないため、(3)!゙ングを寝室と兼悋て使用している。しかし (2)、(3)は長期の居住には問題が多い。

いずれにしても、これらの住み方は、住宅が「老いと死を迎える 場」としてもつ重要な条件の一つに、「一緒に住んでいる家族の気 配を感じつつ眠れること」があることを示している。

\section{8. 日常生活の維続一住生活のアイデンティティ}

日常生活の中で自らが進んでする行為の幅は、病気の進行と並行 して狭ばめられている。しかし、動作能力の判定が境界、軽度、中 等度の者は、以下に示すように、残存能力を活かして、同居家族も 継続を期待するようなさまざまな活動をしている。

\section{8-1. 趣味的活勒の継䌇}

(1)テレビを楽しむ一特に軽度までの高齢者は大相撲中継や、のど 自慢、民謡、時代劇などを好んで見ている。この場合、人により必 ずしも内容は理解していないし、自分で千やン机を選択している訳では ない。(2)本を見る一軽度のものでも雑誌や本などの文字類を䛨むも のは少ない。しかし本調查対象の 31 人の中にメモを書いたり、新 聞や雑誌を手に取るものも 2 〜 人いる。(3)モノづくりを楽しすー デ伪ービスで教わった人形作りを自宅でも続け、知人に上げて楽しむ ような新しいものに取り組める者もいる。(4)家事を続ける一軽度の 女性には、料理の下準備や内職を手伝っている例も少数ながらみら れる。また洗濯物をたたんだり、片づけ、戸締まりを自分の仕事と 決めているものもいる。ただし、火はどの家でも使わせていない。

\section{8-2. 生き物とのつきあい}

(5)草花を育てて楽しむ一これをする者恃多い。農家出身で土いじ りが好きなく気仙-1・84歳・境界〉は通路脇や廊下にまで観葉植物を 並べ、他人の土地まで出かけていって花を植えたり、〈田尻-3・86歳 ・境界〉は途中の道路横断が危険なので止めるように言われているの

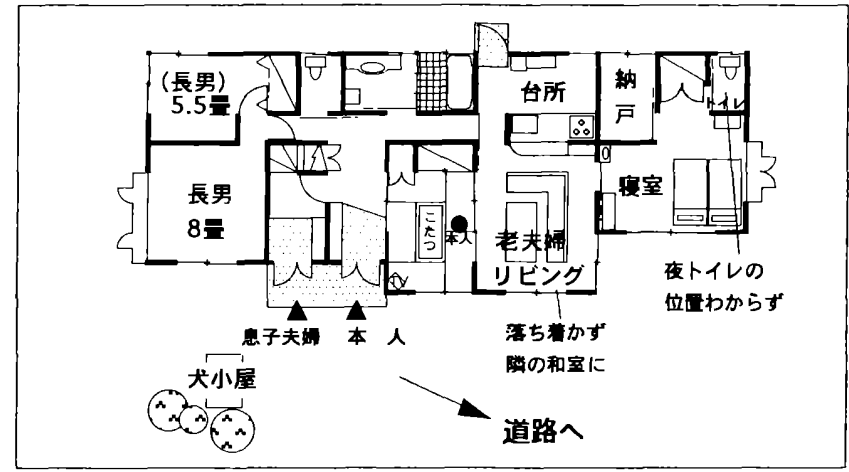

図-1. 親子 2 望带を分離した住宅での住双方例（仙台-4）

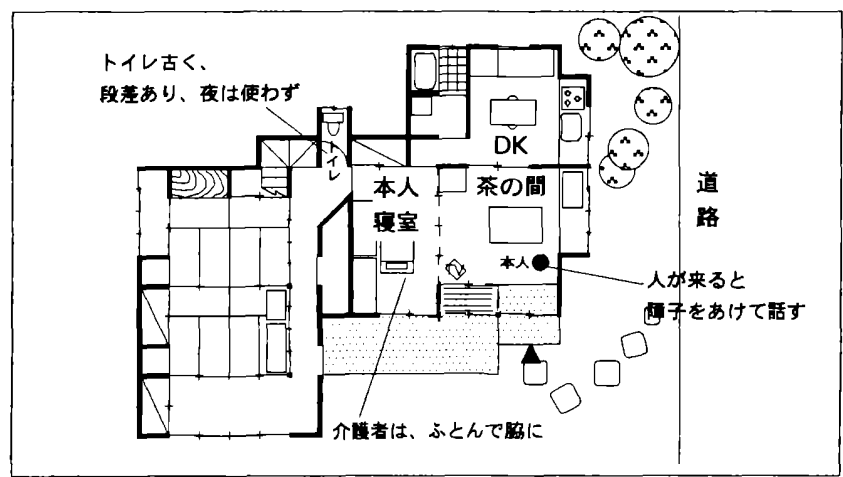

図ー2．誛室と茶の間を続き閒にした住み力例（気仙－2）

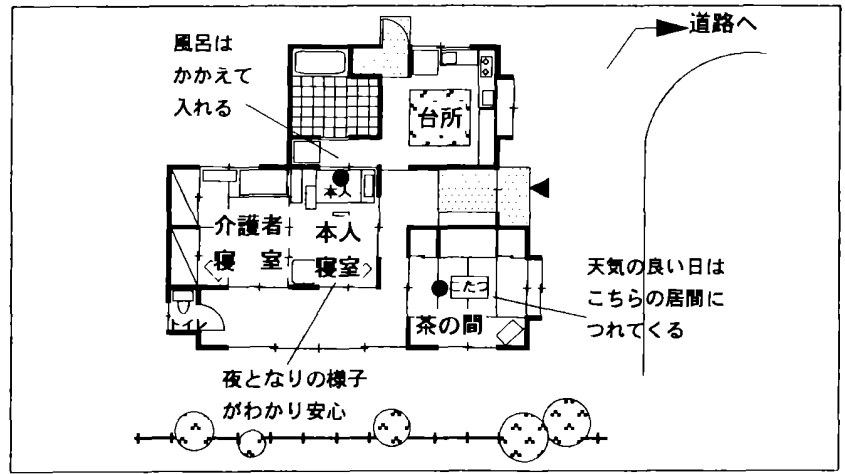

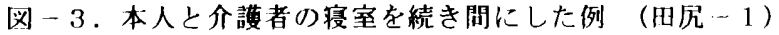

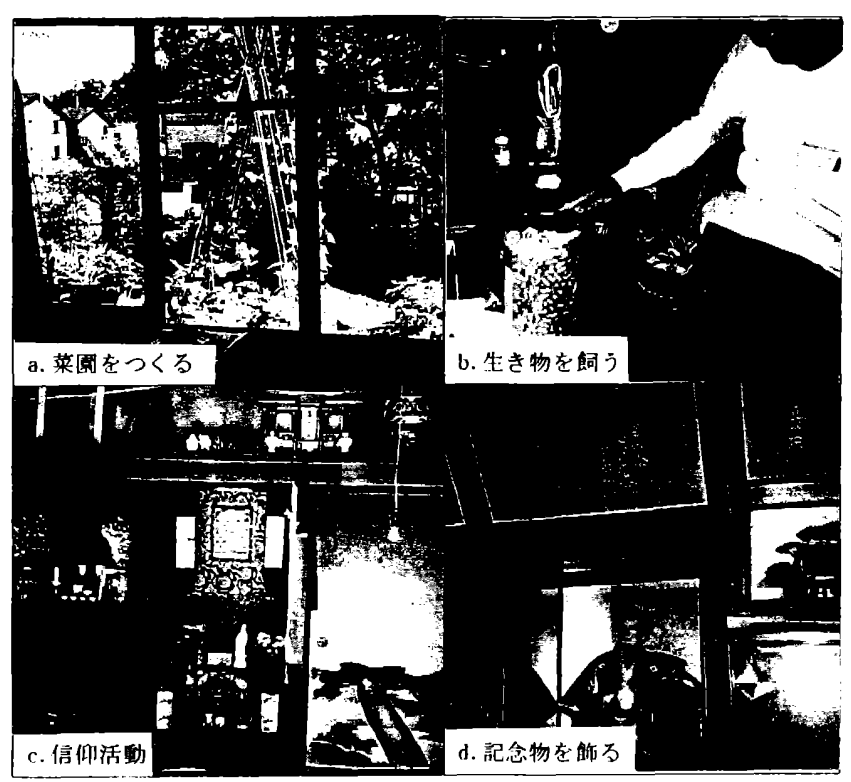

写真 4. 住生活のアイデンティティ 
に介護者のスキを見て畑に行くという。また自分ではあまりしない のに、菜園の作り方をいろいろ指示したり、20年以上も手を入れて いる植木が気になり長期外出できないという者もいる。(6)犬や猫、 小鳥などを飼う一これらに毎日話しかけながら慨をやったり、老犬 を連れて散歩する事例なども見られる。

\section{8-3. 倍仰活動の継綍}

(7)神棚や仏壇に花や水をあげるーこれを自分の仕事にしていて他 の者にはさせない例は男性に何人か見られる。またく田尻-2・93歳・ 軽度〉は、らちわ太鼓を叨き念仏を唱えることが日課で、時に昼夜を 取り違え夜中に太鼓を吒き出すことがある。ちなみに、対象の仙台 の新築住宅には神棚をもつ住宅はみられなかった。

\section{8-4. 家・家族の記憶}

(8)昔の写真を眺める一茶の間の自分の席の横のケースに写真を起 き、それを絶えず眺めている上うな回顧型は多い。(9)生家や父母を 懐かしむ一少年・少女時代を過ごした家、これは父母への想いと重 なっているようである。〈仙台-2〉は現住宅を建てて12年になるのに、 ここは借家だから早く自分の家に帰りたいと言い、〈仙台 $-8 \cdot 61$ 歳・ 境界〉は行方不明になった後、仙台駅で保護されていた。鄉里の農村 に帰ろうとしていたという。(10)家族を心配するーく気仙 $-3 \cdot 83$ 歳・中 等度〉は入院中やショート败价も家のことが心配で、「家にお金はある か」「早く帰ってご飯の支度をしなければ」と絽り返す。現在の家 から転出した子や孫のことを心配する事例もあるが、相手の顔が見 えない電話での通話は次第に用をなさず、音信と記憶が途絶えた事 例がむしろ多い。

\section{8-5. 家族との会話、近隣とのつきあい}

(11)家族との会話を楽しむ一発病後あるいは事故後、以前上り多弁 になったという例は少ないがある。しかし多くは病状の進行と共に 塞黙になっている。それでも対象の高齢者仕在宅であるために、絶 えず声を掛けてくれる介護者がいることが大きな特街である。(12)家 族以外の人との交流を楽しむ一家庭への訪問客に自分の存在をアピ ールするように話に混ざり、会話を理解していることを示寸例や、 昔から出ていた自営の店に顔なじみの客が来ると顔を出したがる例 などもある。中にはく仙台-8〉のように、旧友や教え子などの来訪は 喜ぶが、知らない客を極度に敬遠する事例もある。(13)近隣との交流 一これは高龄者を楽しませるだけではなく、介護世帯をも助けてい る。しかし、これには地域差が大きい。田尻や気仙沼の場合は、出 かける時に声を掛ければ話し相手になっていてくれる隣人や、散步 がてら何時でも立ち寄れる町内の知人宅もある。農村地域では土間 から顔を見せ、茶の閒の高齢者に声を掛けてくれる人なども見られ る。过-5）例数は少ないが、近隣の者に痴呆症状、特に問題行為を 話したがらず、ほとんど交際のない事例もないわけではない。しか し、本調查の対象となった事例からは、互いの居住年数が長く濃い 交流をもっている小規模都市・農村という地域が、痴呆性高龄者の 在宅生活を支えていることがわかる。一方、大都市で、郊外住宅地 の対象が多かった仙台の場合は、15の事例を見る限り、明らかに 近隣との交際は薄い。挨拶程度は寸るものの、介護の助けなどを頼 むような関保のものはごく少ない。これらの場合はほとんどが、介 護で困った時は血縁のあるものを頼っている。

以上のような残存能力を活用した自由で皘極的な活動の特徴は、 第一には、大きくはその人の現在の生活動作能力に規定されており、
重度では自ら表現できる行為が極めて限られたものになっている。 しかし、第二には、中等度までのものは、この活動は非常に多様で 年齢や動作能力を超えて、まさに「その人らしさ、その人の生活ら しさ」を表現していることが少なくない。ことに高㱓者が若い頃か らずっとし綍けてきたことや、こだわりをもっている行為が多いだ けに、そこには一層、個性が表れている。第三には、これらの行為 の継続は、介護者をはじめとする家族や訪問者、近隣の人々などの 協力によって、成り立っているものが多いことである。

\section{9.まとめ}

住居形態や生活様式、近隣関係などが異なると考えられる 3 地域 で、痴呆性高齢者の在宅生活の実態を調查し、そこでの問題と空間 条件の関係を探った。対象の痴呆性高齢者には、〈仙台 -13 〉事例の ように、介護者が「少し前までは地獄の状態だった」と言うものも 存在している。しかし一方で、消し去ることが出来ない病状悪化一 の不安や、ケガの危険と隣り合わせにいながらも、その中で、家族 の慗命な介護と地域社会や公的支援などに支えられて、日常生活を 損なわれるものが少ない形で継繶しているものを多く見ることがで きた。その中で、第一には住宅計画と関わって、日中の居場所や葠 室のとられ方と屋外や介護者の生活の場との位置関係に特質が楒め られること、とりわけユカ坐や、続き閒のもつ連続性・開放性を見 直してみる必要があること、また住宅改造時期やその範囲により一 層、適切な検討と助言が求められていることなどの知見を得た。 また第二の居住施設計画にも反映されるべき点として、現在、在宅 で生き生きとした日常生活の継続を支えている条件を整理し、(1高 龄者の性格や過去の生活習慣などを理解している人や、(2)それが出 来たことを一緒に喜んでくれる人がいること。さらに、場の条件と して、従来から高齢者の施設計画で指摘されている(3)安全性の確保 に加え、(4)室内に持ち込む物が増えるので広さの確保、(5)壁面や開 口部越しに馿染みのある物品や景色が見えること、(6)介護者の生活 の場と密接な関係にあること、とりわけ、(7)隣人や知人との対応な どの関倸づけが重要であること、などを明らかにした。これらは大 都市部の新しい住空間が失いがちな空間条件に関わる問題である。

〈謝辞〉 調查にご協力下さった対象の方々、3市町の保健福祉 課の職員各位、並びに調查を協同していただいた東北工業大学助手 の笹本哃氏に感謝いたします。なお本研究は三菱財団の社会福祉事 業助成を受けた「痴呆性高齢者の住生活に関わる空間計画手法の研 究(代表 菅野 實)の一部である。

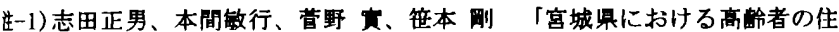
宅事情に関する䀦查報告」 日本建築学会技術報告集第 2 号 1996.3 .

洁-2）小林敏子、播口之朗、西村 健、武田雅俊ほか「行動稓察による疾呆患 者の精神状態評価尺度 (NMスタ一- ) および日常生活動作能力砰洒尺度 (N-ADL) の作成」臨床精神医学、1 7 ，1653-1668.1988. のうち、基本的な身体 的ADL測度のN-ADLを用いた。

壮-3)古贺紀江、高㛢鹰志「一人暮らしの高龄者の常座をめぐる考察 高䖋者 の住居における居場所に関する研究その1」日本建築学会尌画系論文 集 No. 494, 1997. で一人暮らし高跉者の居場所の形成が样述されている。 壮-4)宮城紧の場合、自治体の高龄者向け住宅一の融 の他、自治体保垏所、 福杫事猛所、建穼士会等による住宅改造相談などが行われている。

生-5)鈴木成文、小林秀樹、菊地成朋、長沢 悟、小川暁子「住居における対

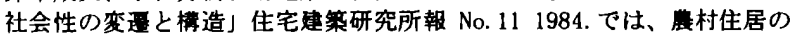
対社会生活の場の棈造と変要が、都市住居との比䖝で究明されている。

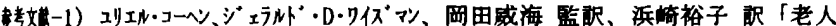
性疾呆症のための理境デザイン」彰国社 1995.12.

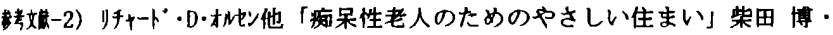
溃端光雄 監訳 ワールドブランシング 1997.11.

[1998年 3 月30日原稿受理 1998 年 7 月 8 日採用決定］ 